\title{
Pleistocene geochronologies for fluvial sedimentary sequences: an archaeologist's perspective
}

Article

Accepted Version

Hosfield, R. T. and Chambers, J. C. (2005) Pleistocene geochronologies for fluvial sedimentary sequences: an archaeologist's perspective. Journal of Quaternary Science, 20 (3). pp. 285-296. ISSN 0267-8179 doi:

https://doi.org/10.1002/jqs.909 Available at https://centaur.reading.ac.uk/3647/

It is advisable to refer to the publisher's version if you intend to cite from the work. See Guidance on citing.

To link to this article DOI: http://dx.doi.org/10.1002/jqs.909

Publisher: Wiley

All outputs in CentAUR are protected by Intellectual Property Rights law, including copyright law. Copyright and IPR is retained by the creators or other copyright holders. Terms and conditions for use of this material are defined in the End User Agreement.

www.reading.ac.uk/centaur 
Central Archive at the University of Reading

Reading's research outputs online 


\section{Author's Original Manuscript - Postprint}

This is an Author's Accepted Manuscript (text only) of an article published as: Hosfield, R.T. \& Chambers, J.C. 2005. Pleistocene geochronologies for fluvial sedimentary sequences: an archaeologist's perspective. Journal of Quaternary Science 20(3): 285-296. 


\section{Pleistocene geochronologies for fluvial sedimentary}

\section{sequences: an archaeologist's perspective}

\section{R Hosfield \& J Chambers}

\section{Introduction}

The past two decades have seen an increasing emphasis upon the timescales of fluvial activity and their variable detection within north-west Europe's fluvial archives (e.g. Rose et al., 1980; Maizels, 1983; Cleveringa et al., 1988; van Huissteden, 1990, et al., 2001; Vandenberghe, 1993, 1995, 2002, 2003; Meinke, 1995; Bibus and Wesler, 1995; Collins et al., 1996; Bridgland, 2000; Maddy et al., 2001; Houben, et al., 2001; Gibbard and Lewin, 2002). These studies of fluvial system dynamics have emphasised a range of variables including climatic factors (direct, indirect and partial forcing), vegetation, river basin characteristics, and internal system factors (e.g. thresholds and response time). All of this work is of considerable significance for the study of Lower and Middle Palaeolithic archaeology in north-west Europe, given the sheer frequency of archaeological assemblages occurring in fluvial secondary contexts (e.g. Wymer, 1968, 1999; Roe, 1981; Bridgland, 1994; Roberts et al., 1995; Tuffreau and Antoine, 1995; Hosfield and Chambers, 2004). These assemblages typically consist of derived lithic artefacts, removed from their original place of discard by water transport and redeposited in fluvial sediments, most typically coarse-grained gravels but also including sands, silts and clays. The age of the archaeology is therefore often complicated by the re-working of artefacts from older sediments into younger deposits (Hosfield and Chambers, 2004). However, prior to investigating those re-working processes it is 
necessary to estimate the age of the sediments themselves and the duration of the depositional events associated with the deposits. It is important to stress here that the fluvial system behaviours characteristic of north-west Europe are frequently not applicable outside of this region - compare for example with fluvial activity and system responses in the Mediterranean (e.g. Macklin et al., 1995; Mass et al., 1998). The following comments and observations are therefore only appropriate to the northwest European region.

The widespread acceptance of the marine isotope record during the late 1980's (Shackleton, 1987) provided the first example of a continuous chronological framework against which the discontinuous, terrestrial archive of fluvial activity could potentially be fitted. This was most notably undertaken by Bridgland (1994, 1995, 1996, 2001), with a model linking terrace formation to the climatic cycles of the Pleistocene, and also emphasising stratigraphic marker events (e.g. the southerly diversion of the River Thames by the Anglian glaciation) and diagnostic artefact assemblages (e.g. the first occurrence of Levallois technique in Britain during late MIS-9 and early MIS-8). Similar chronological frameworks have also been developed for the Meuse river system in north-west continental Europe (e.g. Van Balen et al., 2000). More recent developments in two dating techniques, optically stimulated luminescence (OSL) and amino-acid ratios (AAR), have promoted the direct dating of fluvial sediments (e.g. Lewis and Maddy, 1999; Hosfield and Chambers, 2002). However, neither the MIScycle terrace models (e.g. Bridgland, 1994) nor the OSL dating of Middle and Late Pleistocene sediments (due to the error ranges) permit the duration of individual fluvial episodes (e.g. channel incision, coarse and fine-grained sedimentation) to be assessed. 
Yet from an archaeological perspective, such knowledge is critical to any interpretation of the archaeological content of fluvial sediments. The behavioural inferences that can be drawn from such assemblages change in type and scope if their encasing sediments were deposited over 100 years or 10 millennia. These timescales of deposition therefore define a minimum chronological unit (referred to here as the MCU), which is fundamental to the interpretation of the archaeological data.

This paper therefore assesses current models of fluvial system development and dynamics in north-west Europe, and considers their relevance to the interpretation of the temporal dimension of Palaeolithic archaeological secondary context assemblages from that region. This review paper is therefore primarily aimed at an archaeological audience, and seeks to highlight recent developments in fluvial system understanding and stress their importance to future Palaeolithic archaeological research in north-west Europe.

\section{A Model of Fluvial Activity over a Glacial/Interglacial Cycle}

Assessing the timescales of fluvial activity and the geochronologies of the resultant sedimentary sequences is partially dependent upon the adopted model of fluvial activity across the glacial/interglacial cycles of the Middle and Late Pleistocene. Current fluvial models are grounded in a long history of research (e.g. Zeuner, 1958; Wymer, 1968; Clayton, 1977; Rose, 1979; Green and McGregor, 1980, 1987; Gibbard, 1985; Vandenberghe, 1993, 1995, 2002, 2003; Bridgland, 1994, 1995, 1996, 2001; Maddy et al., 2001; Gibbard and Lewin, 2002). From the earliest models onwards, several authors emphasised a direct link between climate and fluvial system evolution (e.g. Sörgel, 1921; Büdel, 1977; Bryant, 1983; Gibbard, 1985), with fluvial sedimentation occurring 
during glacial periods and river incision between successive terraces taking place during the interglacials. However, a number of observations have contradicted this notion of a direct link (see Vandenberghe, 2003: 2054-2055 for a complete discussion):

- The presence of interglacial sediments within cold-climate terrace sediments (e.g. Green and McGregor, 1980; Bridgland, 1994).

- The relatively thin river terrace deposits in comparison to the duration of the glacial periods in which they were formed.

- The absence of river incision during the Holocene (prior to anthropogenic deforestation), in favour of a state of equilibrium between erosion and deposition.

- River incision during cold periods (e.g. van Huissteden, 1990, et al., 2001), although typically in association with climatic transitions during these cold phases (Vandenberghe, 1993).

- The presence of braided, anastomosing and meandering rivers in both cold and warm stages, as opposed to the traditional notion of braided/cold-climate and meandering-anastomosing/warm-climate associations.

These observations and developments have all highlighted the complexity of fluvial development, and the following generic framework therefore reflects current models and interpretations of the data. The framework is primarily based on models developed for lowland UK river systems (Bridgland, 1994, 1995, 2000, 2001; Maddy et al., 2001; Gibbard and Lewin, 2002) and lowland river systems in the Netherlands (Vandenberghe, 1993, 1995, 2002, 2003): 
1. Full Glacial Phase: river systems are broadly stable (Bridgland, 1994, 1995, 2000, 2001; Vandenberghe, 1995), reflecting a number of factors. These include: the adjustment of the rivers to Arctic Nival type discharge regimes (annual snow-melt discharge), with these flooding events redistributing the existing sediments stored upon the floodplain (Bridgland, 2000); the eventual shutdown of thermohaline circulation (the circulation of ocean waters is driven by density differences, controlled by sea water temperature and salinity) during cold stages and associated movements of the polar front, resulting in depressions tracking further south, the reduced frequency of high magnitude rainfall events, and a reduction in flood frequency to the nival-type (Maddy et al., 2001); and the replacement of braided river sedimentation (reflecting irregular discharge regimes and considerable sediment availability during the earlier part of the cold phase) with a phase of decreased fluvial activity, a relative erosion/aggradation balance, and increasing aeolian activity (Vandenberghe, 1995). While both Vandenberghe (ibid.) and Gibbard and Lewin (2002) identified an incision phase at the beginning of the glacial, Gibbard and Lewin (ibid.) also proposed active braidplain deposition of gravel and sand during the full-late glacial stages of the climatic cycle. This latter activity is absent in Vandenberghe's (1995) Netherlands' systems, and this difference is a valuable reminder of the importance of variations in local energy conditions: in this case, the higher energy of the UK systems produced larger quantities of coarser sediment for braidplain deposition. Overall however, there are a series of shared, key observations with respect to fluvial activity during the glacial phase: 
- Coarse-grained (gravel and sand) sedimentation occurs within braided river systems.

- Sediment is redistributed within the existing floodplain and new material is introduced onto the floodplain from the adjacent slopes.

- Sedimentation events occur in response to annual snow-melt events.

- The system is broadly stable.

Gibbard \& Lewin (ibid: 194) also suggest that only the terminal phase of braided river sedimentation activity will be preserved. This is based on modern analogues for active braided river systems, which suggest that lateral channel shift by bank erosion is both rapid and spatially extensive (the surface layer of entire alluvial valley floors may be reworked in a matter of decades). Under such conditions, it is probable that nival-regime sediment redistribution and reworking activity will produce a preserved fluvial archive that was only deposited during the terminal part of individual, cold-climate phases. This has clear implications for the interpretation of re-worked archaeological material.

2. Late Glacial/Early Interglacial Transition: rapid fluvial incision and aggradation are widespread characteristics of the cold/warm climatic transition (Rose et al., 1980; Vandenberghe, 1995; Collins et al., 1996; Bridgland, 2000; Maddy et al., 2001). Huisink (1997) and Vandenberghe (1995) highlight vegetation as a key factor, with plant recolonisation influencing soil erosion and evapotranspiration rates. In general, evapotranspiration initially remains low, resulting in large river 
discharges, and while vegetation restoration is retarded relative to increasing temperature, it is still sufficient to stabilise soils and consolidate channel banks. The resulting combination of high run-off, bank stability and reduced sediment load results in incision and meandering. Finally, erosion is replaced by aggradation, in response to decreasing discharges (resulting from increased evapotranspiration). These key changes in sediment and water supply were highlighted by Maddy et al. (2001), who also emphasised changing patterns and instabilities in the North Atlantic atmospheric and oceanic circulation that probably led to increasing frequencies of deep depressions tracking across the UK. These result in higher frequency and higher magnitude rainfall events, which are subsequently reduced by the completion of the global climatic adjustment, which brings atmospheric and ocean-circulation to a broadly stable condition. In contrast to the above models of incision and aggradation, Gibbard and Lewin (2002) propose a model of channel pattern inheritance during the glacial/interglacial transition. However the clear evidence of downcutting at the beginning of the Lateglacial and during the Lateglacial/Holocene transition (Maddy et al., 2001; Antoine et al., 2003; Pastre et al., 2003), demonstrated by the deep incision of Early Holocene valleys in many unglaciated river basins in southern England (e.g. the Upper Thames) and northern France (e.g. the Selle valley and the middle River Seine basin), supports the incision and aggradation models which are adopted here.

3. Interglacial Phase: until recently the overriding view of fluvial systems during full interglacial conditions was of subdued fluvial system activity, with relatively 
low-energy sediments being deposited across the inherited floodplain, valley bottom stability, lateral migration of the river across the alluvial plain, and soil formation (Vandenberghe, 1995; Maddy et al., 2001). However Gibbard and Lewin (2002: 198-204) have highlighted the complexity of the interglacial phase, with a multi-stage model of lowland river behaviour in response to an interglacial climatic cycle:

- Late glacial/early interglacial transition: river flow adjusts to decreased seasonal contrasts, permafrost melting and the introduction of year-round precipitation and infiltration. This results in stabilisation of the inherited channels, due to insufficient energy for gravel transport or channel form modification. A complex of surfaces for plant colonisation and soil development is provided, while vertical accretion of fine-grained, organic, fossiliferous sediments begins in braidplain depressions and abandoned channels.

- Full interglacial (early phases): the establishment of forest vegetation further diminishes variations in river flow (the soil-vegetation system stabilises ground surfaces and delays flood responses) and severely reduces inorganic sediment supply to alluvial systems. Stream flow is relatively slow throughout the year (except following exceptionally severe storms), channels stabilise, and minor, fine-grained, organic deposition is predominant in the open channels

- Full interglacial (late phases): continued infilling of floodplain depressions and channels leads to a decrease in the number of flow 
routes. This restriction of streams to relatively few channels leads to increased periodic flooding and widespread vertical accretion across the majority of the floodplain surfaces. The flowing channels (typically stable meandering and/or anastomosing) remain relatively fixed in the positions inherited from the previous late glacial, although the channels are not necessarily in contact with the cold-stage sediments.

- Late interglacial: sedimentation initially continues during the late temperature phase, but as the climate deteriorates it is assumed that the mean annual temperature declines, vegetation retreats and thins out, discharges become more seasonally variable and extreme flood events may become more frequent. Overall, increased overbank flooding is expected, delivering thick accumulations of sands and fines (e.g. clays and silts (Gibbard and Lewin 2002: 192)) across the floodplain surface. This flooding will also be accentuated by the restriction of the river to single, deeper flow channels.

- Early glacial: the return to predominantly treeless conditions (regional, herb-dominated early-glacial grassland) is associated with typical coldclimate regimes, with highly peaked flow discharges. Energy is therefore provided for stream rejuvenation, channel enlargement, remobilization of coarse debris, rapid removal of fines and substantial incision into the accumulated floodplain deposits (into which pollen and spore fossils are also reworked). The redevelopment of permafrost and inhibition of infiltration ensures rapid surface water flow, which combined with slope erosion and solifluction provides a source of coarse sediment. The initial 
absence of coarse sediments results in fluvial incision, the removal of fine alluvium, and the planing off of the upper parts of floodplain and channel deposits by laterally mobile, incising rivers, during the early period of the interglacial/glacial transition.

Gibbard and Lewin (2002) emphasise the unequal preservation of sediments from different parts of an interglacial: sediments laid down early within a warm stage are far more common in the geological record than those from later in the same stage, due to the widespread accommodation space that is available for sedimentation during the early interglacial period and the limited space available during the later interglacial, when the sediments are also extremely vulnerable to the subsequent high energy rivers of the succeeding glacial phase. The variable fragmentation and re-working of the interglacial sediments according to the nature of the valley (e.g. narrow valleys with steep slopes compared to wide, unrestricted valleys with non-cohesive or unresistant substrates) is also stressed, along with the common preservation of erosional contacts between the subsequent cold-climate gravels and sands and the underlying interglacial finesediments (implying the removal of pre-existing sediments and an unknown time interval).

4. Late Interglacial/Early Glacial Transition: fluvial erosion and aggradation is again a key characteristic of the warm/cold climatic transition (Vandenberghe, 1995; Bridgland, 2000; Maddy et al., 2001; Gibbard and Lewin, 2002). Vandenberghe (1995) emphasises an initial drop in temperature, resulting in 
lower evapotranspiration and a higher amount of overland flow. While vegetation persists for a short period, soil and river bank stability is maintained, leading to an increasing ratio of river discharge to sediment supply, resulting in fluvial incision. Subsequently, the deteriorating climate disrupts vegetation cover, resulting in soil destabilization, increased sediment supply and fluvial aggradation within the newly formed accommodation space. Bridgland and Maddy also emphasise incision at the interglacial/glacial transition as a result of changes in sediment and water supply (see Bridgland, 2000; Maddy et al., 2001 for full details of this model).

The models are summarised schematically in terms of episodes of fluvial incision, erosion, sedimentation and preserved sedimentation (Figure 1), drawn from the above discussion. From the perspective of archaeological secondary context assemblages occurring in fluvial sediments, a critical question concerns the duration of these episodes, whether phases of sedimentation or incision/erosion.

Figure 1: conceptual model of fluvial activity over a glacial/interglacial/glacial cycle (after Vandenberghe, 1993, 1995; Bridgland, 2000; Maddy et al., 2001; Gibbard and Lewin, 2002). $S=$ sedimentation; $P S=$ preserved sedimentation; $I=$ incision (floodplain downcutting); $E$ = erosion (localised). The MIS curve is drawn from core V28-238, spanning the period from the end of MIS-13 to the start of MIS-9 (Gamble 1999: Figure 2.4).

\section{The Duration of Fluvial Activity}

Vandenberghe (1995) has highlighted four distinct timescales with respect to river development and the relationship between river dynamics and external factors: 
1. 100,000 s of years (glacial/interglacial sequences). At these scales, fluvial evolution is broadly climatically dependent, within its tectonic framework, in accordance with Maddy et al. (2001).

2. 10,000s of years (a single glacial/interglacial cycle). Fluvial activity and response is now determined by the derived impacts of climate: vegetation, soil cohesion and run-off. Short unstable phases alternate with long periods of inactivity, with the unstable phases occurring at the major climatic transitions, a theme recently emphasised for Middle Pleistocene sequences by Bridgland (2000), Maddy and Bridgland (2000), and Maddy et al. (2001).

3. 1,000 s years (single phases of instability). At this scale, the fluvial response is governed by the intrinsic evolution occurring within the system, as demonstrated by Howard and Macklin (1999).

4. 100s of years (lower order climatic changes). The well-pronounced effects of local thresholds are most striking at this scale, including climatic thresholds (the duration and intensity of climatic change) and landform and sedimentary thresholds (valley gradient, and the diameter and quantity of sediment to be transported).

From an archaeological perspective the most important element of Vandenberghe's (1995) timescales concerns the observation that short unstable phases alternate with long periods of inactivity. The key concern remains the issue of how short the short unstable phases are? Vandenberghe (1995) suggests that these single phases of instability are 1,000 s of years in duration, although it is emphasised that these phases 
are still not characterised by constant fluvial activity. This is illustrated with respect to precipitation, where the intensity of precipitation and its seasonal distribution are more important than annual values in determining the processes of erosion and deposition. Thus, extreme events at a recurrence interval of years or tens of years leave the largest imprints in the production of sediment (Vandenberghe, 2003: 2055). This however still leaves the question of the duration of these short, unstable phases, during which a combination of factors (climatic, climate-derived, climate-dependent, and non-climatic) influence fluvial development (Vandenberghe, ibid.).

\section{Fluvial Event Chronology: Extant Studies}

Short synopses of six extant studies of fluvial deposition are presented as examples of the geochronologies associated with the short-term phases of fluvial activity as highlighted by Vandenberghe (1995). They represent a wide geographical catchment across north-west Europe, different river types, and cover the Devensian, Late Glacial and Holocene periods. The implications of these characteristics for the use of the case studies as analogues for Middle Pleistocene sedimentary sequences are considered below.

1. Cleveringa et al. (1988) highlighted episodic river adjustments over the last 15,000 years for a series of small river basins in Belgium and the Netherlands (Figure 2). The model linked the river adjustments with variable discharge parameters (e.g. the amount of precipitation and degree of evapotranspiration), and emphasised the relatively short duration of the river adjustment phases (suggested to be $c .1,000$ years from pollen and radiocarbon data). Cleveringa et 
al. (1988) also drew attention to the differential responses of individual river systems: in other words, not all river systems react with the same intensity, for the same length of time and to the same degree, to changing conditions (climatic and/or vegetational).

Figure 2: relative curves of climatic parameters related to river adjustments since the Upper

Pleniglacial, for selected river systems in Belgium and the Netherlands (Cleveringa et al., 1988: Figure

5)

2. Houben et al. (2001; Houben, 2003) recorded short-lived fluvial sedimentation events for small and mid-scale rivers in the Hessian Depression (Hessische Senke) in Central Germany. Changes in fluvial activity during the Late Glacial and early/mid Holocene were linked to established climatic stages, with radiocarbon-dated channel fills (Table 1) indicating sedimentation events occurring over centennial rather than millennial timescales (e.g. channel filling between 15,745-15,105 cal BP and 14,485-14,135 cal BP (Houben et al., ibid: 252)).

Table 1: selected radiocarbon dates from the Wetter valley near Muenzenberg (after Houben et al., 2001:

Figure 3)

3. Vandenberghe (1993, 1995; Table 2) documented rapid phases of fluvial activity for the Dinkel and Maas rivers (Netherlands). Up to $8-9 \mathrm{~m}$ of incision has been recorded in the Dinkel river valley in the eastern Netherlands, between 
c. 13,000 BP (the Weichselian Pleniglacial/Late Glacial transition) and $c$. 11,800 years BP. This phase of fluvial erosion was followed by relatively rapid aggrading of gullies, which was almost completed by the end of the Late Glacial (c. 10,000 BP).

Table 2: chronology of fluvial events for the Maas (Netherlands) river during the Late Glacial, with data for the Warta (Poland) included for comparison (Vandenberghe, 1995: 635-636). Chronologies in noncalibrated radiocarbon ages.

4. Rose et al. (1980) documented fluctuating phases of channel stability and instability for the River Gipping at Sproughton, Suffolk in the UK. Radiocarbon dates and ages inferred from a coleopteran assemblage (Rose et al., ibid: Table 12.1) documented the erosion of discontinuous gully channels between 11,300 and 11,000 years BP, followed by braided and meandering river sedimentation of sands and gravels between 11,000 and 9,500 years BP.

5. Collins et al. (1996) recorded changing fluvial activity for the River Kennet, in central southern England. Evidence from the site at Woolhampton highlighted a series of major changes in fluvial activity, linked by pollen and macrofossil data to broad climatic fluctuations, spanning the Last Glacial Maximum through to the Younger Dryas Stadial.

6. Maddy et al. (2001: 32-33) highlighted the archiving of higher resolution signals of climatic change within individual terrace aggradations, with specific reference to the Northmoor terrace of the Upper Thames valley of the UK (Figure 3). The durations of these short-term climatic changes are proposed to 
be in the order of one to several millennia (Vandenberghe's (1995) $3^{\text {rd }}$ timescale), although few specific examples are presented (reference is made to cold- and warm-climate shifts within a glacial, such as the Devensian Late Glacial interstadial and the Younger Dryas).

Figure 3: conceptual model of the climate-driven sedimentary architecture of the Northmoor Gravel of the Upper Thames valley (Maddy et al., 2001: Figure 5)

This short review raises a number of complicating factors with regard to the issues of fluvial event chronology. These are considered fully later in the paper, but are summarised here:

1. Different river systems react with varying intensities, over different lengths of time and to different degrees, to changing climatic and vegetational conditions. This reflects variations in threshold conditions, linked to local and regional fluctuations in physiography, geology, climate, tectonics, and sea-level (Cleveringa et al., 1988; Vandenberghe et al., 1994; Kasse, 1998; Vandenberghe, 2002; Houben et al., 2001; Houben 2003).

2. Different stretches of single river systems also react differently (reach-scale divergent responses), due to local fluctuations in discharge magnitude and frequency, sediment supply, vegetation coverage and type, channel gradient, climate, and terrain morphology (Houben, 2003).

3. The stratigraphic sequences of most (if not all) drainage basins are incomplete as a result of the local dominance of erosional discontinuities, which typically do 
not occur throughout the system. For example, sedimentation in the lower parts of basins can be chronologically associated with erosional features in the upper part of the same basin (Cleveringa et al., 1988).

4. Intrinsic fluvial system changes can lead to localised aggradation or incision (e.g. within a single system reach). Examples might include short-term sediment starvation, resulting in bed incision, and sudden large-scale debris flows onto the valley floor, leading to bed aggradation. It is emphasised that such localised adjustments are difficult to resolve in the stratigraphic record, although their presence is likely (Maddy et al., 2001).

5. Complex cut and fill architecture may be present in early terraces, but the highly fragmentary character of the record hinders their detection. The successful interrogation of the high resolution record for earlier periods will therefore require the widespread application of the latest geo-chronological tools (Maddy et al., 2001).

However, despite these many complexities, what is apparent is that relatively rapid chronologies for fluvial events are a widely shared characteristic of fluvial systems located over disparate parts of north-west Europe. While the nature of the fluvial activity may vary, in most cases it appears that episodes of fluvial incision/erosion and aggradation (both coarse-grained and fine-grained) occur across time-spans stretching over a few hundred, or at most a few thousand, years. This has clear implications for the archaeological interpretation of the European Palaeolithic stone tool assemblages occurring in association with the fluvial sedimentary units of the Middle and Late 
Pleistocene. In combination with the generic models of fluvial activity across the glacial/interglacial cycle (see above), it can be proposed that:

1. The increasingly high-resolution ice core records (e.g. Anklin et al., 1993; Meese et al., 1997; Petit et al., 1999; Stuiver and Grootes, 2000; Johnsen et al., 2001) have revealed evidence for multiple, short-term climatic fluctuations, occurring at both the major interglacial/glacial/interglacial climatic transitions and within individual MI stages (glacials and interglacials).

2. However, river system responses to minor climatic fluctuations (e.g. those within glacial and interglacial stages) will tend to be sporadic, reflecting threshold conditions and other local factors.

3. By contrast, the fluvial activity associated with the major climatic transitions will be more commonly preserved within the fluvial archives over the long-term, reflecting threshold factors and variable preservation potential.

4. Lithic artefact assemblages occurring with fluvial sedimentary secondary contexts are unlikely to have lain undisturbed on river floodplains and/or channel margins for more than 2-3,000 years between major/minor episodes of fluvial activity. This is based on consideration of the 21 interstadial events documented for the last 80,000 years (Watts et al., 1996), and van Huissteden's (1990) age estimates for the Hasselo Stadial (41-38.5 kyr BP) and Hengelo Interstadial (38.5-37 kyr BP).

5. The terminal transportation and deposition of stone tool artefacts into individual sedimentary units during episodes of fluvial activity occurred relatively rapidly. 
These points do not take account of the issue of artefact re-working from older deposits (see below and also Hosfield \& Chambers, 2004), but they raise two critical issues, which are discussed in the following two sections:

1. Are models of fluvial activity during the Late Glacial and the early/mid Holocene period applicable to the interpretation of fluvial sedimentary sequences during the Middle Pleistocene?

2. Do appropriate geochronological and geoarchaeological tools and techniques exist for the detection and dating of the high resolution fluvial archive within Middle Pleistocene sedimentary sequences?

\section{Holocene \& Lateglacial Models: Viable Analogues?}

A critical issue concerns whether high-resolution Late Glacial and Holocene models of fluvial system development are applicable to the interpretation of Middle Pleistocene sequences. Resolution of this issue focuses upon two points: (i) was fluvial development overtly influenced by anthropogenic activity during the Holocene period?; and (ii) if not, are the Late Glacial and Holocene climatic and environmental conditions comparable to those of the Middle Pleistocene?

The question of anthropogenic influence is certainly pertinent for many studies of fluvial systems dating to the mid-late Holocene, and its effects are well documented (e.g. Schirmer, 1988, 1995; Macklin and Lewin, 1993; Bibus and Wesler, 1995; Brown et al., 2001). It is therefore suggested that the use of analogue models for fluvial system activity and development should be restricted to the Late Glacial and early Holocene 
periods (as with the examples included in the previous section). Fluvial development in these periods shows no apparent evidence of anthropogenic impacts, but continues to provide a relatively high-resolution radiocarbon chronological record (a key requirement for the analogue models). This however leads directly to the second key issue - whether the climatic and environmental conditions of the Late Glacial and early Holocene periods are applicable to the Middle Pleistocene?

Throughout the last 12 MI stages, climate changes have been dominated by lowfrequency (100 ka), eccentricity-driven cycles (Maddy et al., 2001), suggesting that the overall pattern of glacial/interglacial cycles over the Middle and Late Pleistocene has remained relatively consistent. However, while the Late Glacial and early Holocene periods essentially document a glacial/interglacial transition, from MIS-2 (the Devensian/Weichselian) into MIS-1 (the Flandrian/Holocene), this transition is complicated by the presence of brief climatic oscillations. The UK's Devensian Late Glacial divides into the Windermere Interstadial and the Loch Lomond Stadial, and continental north-west Europe's Weichselian Late Glacial further splits into the Bølling Interstadial-Older Dryas Stadial-Allerød Interstadial (further sub-division of these stages is not possible with regard to fluvial activity, as their individual effects have yet to be demonstrated), and the Younger Dryas Stadial (Lowe and Walker, 1997: 9-13). It is clear from the previous case studies that these short-lived climatic oscillations played an important role in the documented phases of fluvial development and rapid activity in north-west European rivers during this period. Were such oscillations therefore common during the Middle Pleistocene? This is difficult to currently assess, but available ice core evidence (e.g. Anklin et al., 1993; Meese et al., 1997; Petit et al., 1999; Stuiver and 
Grootes, 2000; Johnsen et al., 2001) is supportive of parallels between the Late Glacial and the early Late Pleistocene and the Middle Pleistocene. The recent Stage 3 Project (van Andel and Davies, 2004) has provided high resolution data from one part of the late glacial/interglacial cycle which indicates strong climatic variability characterised by rapid climatic oscillations (as discussed above with respect to the Late Glacial). Van Huissteden et al. (2001: 75) have argued that stage 3 can be considered to represent 'average' glacial conditions. They suggest that the variability may be an intrinsic property of such 'average' glacial conditions, with only glacial and extreme glacial conditions characterised by far less variable climates.

Overall therefore, while the situation is not yet certain the available evidence appears to suggest that the climatic and environmental patterns of the Late Glacial are replicated throughout the Middle Pleistocene. Given the apparent link between rapid climatic oscillations and relatively short phases of fluvial activity during the Late Glacial it is proposed here that similar relationships would also have been prevalent during the Middle Pleistocene. However, there is a further issue, namely that the presence of rapid climatic oscillations will not always result in fluvial activity and even if it does, such activities may not be preserved over the long-term within the fluvial archive as sedimentary units or erosive features. For example, a fluvial response to the pronounced Hasselo-Hengelo stadial/interstadial event has scarcely been found in the rivers of the Netherlands (e.g. van Huissteden et al., 2001). This may be due to the similarities in duration between the climatic oscillations (centennial or millennial) and the response times of the river to distinct climate change (the Maas took several hundred years to respond to the Weichselian Pleniglacial/Late Glacial transition). Given such similarities, 
it is not surprising that fluvial systems do not always react to climatic changes of limited duration (Vandenberghe, 2002: 19), and it is also apparent that climatic events need to be of longer duration in order to affect larger fluvial catchments (Vandenberghe, 2003: 2058).

Moreover, the critical fluvial system threshold values (Vandenberghe 2003: 2057-2058) that must be exceeded also vary on a regional basis in absolute and relative values. For example, the energy available for sediment removal and transport is determined by river gradient as well as discharge, while the energy required is expressed by the amount and grain size of the river's sediment load. Catchment size will also influence river responses, due to the differential increase in small basins in the proportion of the catchment area that is only occupied by surface runoff under permafrost conditions. This trend results in river responses to permafrost development or degradation being more pronounced in smaller rather than larger catchments. Finally, Maddy et al. (2001: 34) have stressed that the sedimentary architecture resulting from low magnitude, high frequency changes in sediment/water budgets (probably due to high frequency climatic events) is small in scale, and therefore is extremely vulnerable to localised erosion.

Given these problems of variable system response and relative preservation, how can fluvial sedimentary sequences be interpreted in terms of a geochronological framework and their archaeological content? 


\section{A Semi-Floating Geochronology}

The critical problem in constructing a geochronological framework for Middle Pleistocene fluvial sedimentary sequences concerns the resolution of currently available geochronological tools. Despite recent advances in, and applications of, optically stimulated luminescence dating (e.g. Prescott and Hutton, 1994; Murray and Roberts, 1997; Lewis and Maddy, 1999; Murray and Wintle, 2000; Toms, 2002; Hosfield and Chambers, 2002; Toms et al., 2004), it is clear that the error ranges associated with sample ages do not allow for the correlation of sedimentary architecture with the individual climatic oscillations identified in the ice core records. Nor does the technique support the correlation of sedimentary units recorded in different sites or different exposures of a single site. However, OSL ages do permit the identification of the age of sedimentary features at the MIS scale (e.g. Hosfield and Chambers, 2002; Toms et al., 2004) and these estimates can be correlated against other sources of geochronological evidence such as amino-acid ratios (e.g. Lewis and Maddy, 1999). This relatively coarse degree of geochronological resolution supports a preliminary framework of fluvial activity over the glacial/interglacial cycles (full glacial-late glacial/early interglacial transition-full interglacial-late interglacial/early glacial transition). In regions with significant rates of uplift (e.g. southern England), these climatically-driven cycles of fluvial activity are commonly preserved as fluvial deposits in association with discrete terrace features (Maddy et al., 2001).

Within this framework, fluvial activity is associated with climatic change, including both the high magnitude, low frequency climatic shifts associated with the glacial/interglacial transitions (and vice-versa) and the minor, low magnitude, higher 
frequency climatic oscillations associated with all phases of the cycle. It is highly probable that not all of these climatic events will be represented within the sedimentary archive of a river terrace deposit. It is therefore argued here (following Bridgland, 1994, 2000, 2001) that the majority of preserved coarse-grained sediments and fluvial architecture probably relate to the major phases of interglacial/glacial and glacial/interglacial transitions, although it is stressed that the current resolution of geochronological dating tools rarely enables this to be unequivocally demonstrated. For example, OSL samples from the terrace deposits at Broom on the River Axe suggest ages of $237 \pm 25 \mathrm{ka} \mathrm{BP}, 279 \pm 20 \mathrm{ka} \mathrm{BP}, 287 \pm 22 \mathrm{ka} \mathrm{BP}$, and $297 \pm 29 \mathrm{ka}$ BP from the organic Middle Beds, whose pollen content is suggestive of an interglacial origin (Shakesby \& Stephens, 1984: 86-87; Toms et al., 2004: Table 2; Hosfield and Chambers, 2004: 44). The sample ages therefore span a range from early MIS-8 to early MIS-7, and cannot provide greater resolution as to the temporal origins of these apparently interglacial sediments. It remains possible that they represent a brief, relatively warm interval at some point during the MIS-8 glacial.

These problems of low resolution geochronological tools, incomplete representation of climatic events within the fluvial archive, and incomplete preservation of sedimentary features in that archive hugely complicate any attempts to define a sub-MIS geochronology. Even where there is a clear sequence of distinct terrace features relating to glacial/interglacial cycles (e.g. as with the Middle and Lower Thames (Bridgland 1994)), the individual sedimentary units and features within the terrace deposits cannot be precisely aged, and only sometimes can they be relatively dated within the cycle. This is typically dependent upon the presence of unequivocal interglacial sediments 
within the terrace deposits, since these can indicate the approximate ages of the sediments lying stratigraphically above and below them. For example, the presence of MIS-7 interglacial sediments in a terrace deposit (securely dated on the basis of fauna, amino-acid ratios and OSL) would suggest ages of the MIS-8/7 transition and the MIS7/6 transition for the coarse-grained sedimentary units above and below them. Yet it cannot be assumed that such sedimentary features (especially those that are small in scale) represent the major climatic transitions, rather than being a fortuitously preserved relic of a short-lived climatic oscillation during an interglacial or glacial phase. Moreover, the stratigraphic sequence and position of sedimentary units can also be misleading, given the potential for extensive erosion and differential preservation in local parts of the deposit.

Yet at the same time what is clear is that these sedimentary units represent sporadic but high magnitude fluvial activity (e.g. nival spring flood events) over relatively short periods of time, perhaps as little as one or two decades, and rarely more than a few hundred years in duration. It is stressed again here that fluvial activity (channel migration, incision, erosion and aggradation) was not occurring constantly during these periods, but that these processes were dominant. We are therefore left with an unusual scenario, in which the chronology of the individual sedimentary features is relatively well understood in terms of its magnitude (primarily $10^{1}$ and $10^{2}$ years — based on Late Glacial analogues), although the exact age of the features remains unknown. These features cannot be related to the climatic oscillations and switches evident in the high resolution ice-core records, both because of the lack of high resolution dating techniques for the deposits (preventing direct correlation) and the complexities of 
system response and sporadic preservation (preventing indirect correlation between the number of sedimentary features and the number of climatic oscillations and switches). The broader age of the features can of course be estimated, based on:

- Geochronological dating tools (e.g. OSL, AAR, faunal and pollen assemblages).

- Geochronological models of terrace sequences and fluvial activity across the glacial/interglacial cycle.

- The spatial scale of the sedimentary features, which is indicative (but no more) of the magnitude of the climatic transition/oscillation with which it was associated.

The geochronology is therefore absolute at the scale of MIS cycles, but is a relative one at the sub-MIS scale, although the chronological magnitude of individual sedimentary features and fluvial events can be estimated on the basis of Late Glacial analogues. We refer to this as a semi-floating geochronology. What does this mean for the interpretation of archaeological materials occurring in secondary context within fluvial sedimentary units?

\section{Implications for Palaeolithic Archaeology}

The implications of the proposed semi-floating geochronological framework for archaeological interpretation operate at two scales:

- Firstly, with respect to the analysis of temporal trends in archaeological data, for example the similarities and contrasts between two assemblages occurring in sediments of different ages. 
- Secondly, with respect to the interpretation of the archaeological assemblages' temporal homogeneity/heterogeneity, in terms of the processes involved in the incorporation of the cultural debris (e.g. lithic artefacts) within the fluvial sediments.

In terms of the analysis of temporal trends, the cyclical terrace-forming frameworks of Bridgland (1994, 1995, 2000, 2001) have provided a mechanism for the analysis and comparison of secondary context archaeological data at the MIS scale for over ten years (e.g. White, 1998; Wymer, 1999; Ashton and Lewis, 2002). However, it is clear from the discussion above that it is currently not possible to analyse and compare secondary context data at the sub-MIS scale in terms of an absolute geochronological framework. Yet this is a highly desirable goal, since it would support the investigation of highresolution research questions, for example whether there is evidence for changing behavioural strategies (e.g. in terms of stone tool manufacture) in response to short-term climatic shifts and limited phases of warmer and/or colder climates. However, even if the appropriate geochronological tools and methodologies were available, it would still be necessary to consider the second issue: the process of artefact and assemblage incorporation within sedimentary bodies and their temporal dimension.

Studies of fluvial system development during the Late Glacial and early Holocene suggest that fluvial events such as channel erosion or floodplain sedimentation occur relatively rapidly, over a few hundred or a few thousand years. These time-scales are likely to be over-estimates, and reflect the limitations of both the Late Glacial radiocarbon chronologies and the stratigraphic resolution of the sedimentary records. The key issue from an archaeological perspective is therefore that the archaeological 
content of a single sedimentary context can be bracketed within a timescale of (at most) several hundred years rather than several thousand or tens of thousands of years. It should be noted that this approach highlights the need for high-resolution recording of fluvial sedimentary sequences with respect to their archaeological content, in particular the sub-division of sediments on the basis of cut and fill features and erosion surfaces. Most important however, is that the temporal bracketing of the archaeological content refers only to the process of the terminal deposition of the artefacts within their sedimentary unit. Prior to this terminal depositional event however, artefacts will have lain on floodplains or stream and river beds for an indeterminate period of time, following their discard by hominins.

However, Late Glacial and Holocene studies suggest that river systems respond to short-lived, low magnitude and high frequency climatic oscillations, albeit not universally and in a complex fashion. The duration of these events is uncertain, reflecting current geochronological resolution, although van Huissteden (1990) suggests estimates of 2-3,000 years for the Hasselo Stadial and Hengelo Interstadial events. Given the evidence for fluvial system response to these climatic oscillations, this would suggest that the potential for heterogeneous (mixed) artefact 'assemblages' to accumulate, undisturbed, upon floodplains through repetitive artefact discard over several millennia or tens of millennia is slight. By contrast it is proposed that artefact accumulations would be re-worked into fluvial sediments every few thousand years. It is stressed that these assemblages are temporal palimpsests (they might of course actually represent single occupation phases but this cannot be demonstrated), but of the order of a few thousand, rather than tens of thousands, of years. It is also noted that the 
time-depth of these temporal palimpsests will vary, most obviously between small river systems, which tend to be most sensitive and responsive to the high frequency, low magnitude climatic oscillations (Vandenberghe, 2003), and the larger systems, in which there is greater potential for undisturbed artefact discard and accumulation over longer time-spans. Unfortunately, despite this assessment of the temporal scales associated with these palimpsests, it is still not possible to address research questions that operate at shorter, centennial scales (e.g. is there evidence in the stone tool assemblage for either 'standardisation' or variability in tool-making over thousands of years).

The considerable evidence for localised erosion of fluvial architecture within Late Glacial and Holocene sequences (e.g. Rose et al., 1980; Vandenberghe, 1993; Collins et al., 1996) is augmented by the fragmentary records for the Middle Pleistocene (e.g. Bridgland, 1994; Maddy et al., 2001) and highlights the potential problem of artefact erosion and re-working. This is one of the most awkward of archaeological problems when dealing with secondary contexts - namely that the artefacts may have been reeroded out of older sedimentary units. Adopting Bridgland's (1994) model of terrace formation it should be clear that artefacts re-worked from the oldest sediments on a terrace feature into the youngest sediments may be spanning two or even three MI stages. There is no simple solution to this problem, although we propose elsewhere that the physical condition of artefacts can be a useful indicator of the degree of re-working (both vertical and horizontal) that artefacts have undergone (Hosfield and Chambers, 2004; Chambers 2004). Nonetheless, it is clear that when dealing with secondary contexts the starting assumption must be that the assemblage is a mixed collection of reworked artefacts of different ages, and that one is dealing with a time-averaged 
palimpsest of the potential order of tens of thousands of years. It is the task of the archaeologist to refine this chronology where possible. It should be clear that these refinements have fundamental implications both for the types of questions that may be asked and for the interpretation of the secondary context archaeological data.

\section{Conclusion}

At the current time the most robust geochronological framework for the analysis of archaeological assemblages in secondary context (fluvial sedimentary units) operates at the MIS scale. This reflects both the current limitations of geochronological tools and extant models of cyclical terrace development and large-scale fluvial activity across the glacial/interglacial cycle. Absolute chronologies at the sub-MIS scale are currently impractical, but the evidence for fluvial activity during the Late Glacial and early Holocene periods has highlighted some important issues with respect to the potential future interpretation of secondary context data:

- Individual fluvial events (e.g. gully erosion, coarse-grained braidplain sedimentation, fine-grained overbank flooding) occur relatively rapidly, with time-scales of an identifiable magnitude of $10^{2}$ and $10^{3}$ years, in partial response to short-term climatic oscillations and change.

- The relatively brief duration of these individual events is a widespread, shared phenomena, although the specific response of individual river systems (and individual reaches within those systems) to the same climatic events can vary markedly. 
- The ice core records indicate a high frequency of low magnitude climatic oscillations during the Middle and Late Pleistocene, occurring within the broader 100,000 year framework of glacial/interglacial cycles and the major phases of climatic change.

These observations and data both highlight the climatic instability of the period, and indicate that there is potential for secondary context assemblages to have accumulated (through discard in the fluvial landscapes) and been incorporated within fluvial sediments over relatively short time-spans $\left(10^{2}\right.$ and $10^{3}$ years in magnitude).

This is important because the secondary context Palaeolithic resource (typically derived assemblages of lithic artefacts, recovered from fluvial deposits) represents a large component of the Lower and Middle Palaeolithic record of north-western Europe (e.g. Swanscombe (Conway et al., 1996) and the Somme Valley (Tuffreau et al., 1997). Despite this the data has received relatively little attention, not least because of the traditional difficulties of establishing the chronological integrity of the assemblages. Consequently, much of the extant research dealing with these data has rarely moved beyond typo-stratigraphic frameworks grounded in the fluvial terrace sequences (e.g. Wymer 1968, 1999; Roe 1981).

By contrast, the high resolution geochronological timescales discussed above offer the potential to ask a wider range of research questions, including issues of standardisation in lithic production, and stasis and change in stone tool technology. However, these geochronological data also highlight the problems of artefact re-working through 
sediment erosion, and it is clear that considerably more work is required to address those problems. We therefore hope that this paper's focus upon geochronological frameworks and fluvial sedimentary contexts has emphasised the potential of secondary context archaeological data and the value of such future work.

\section{Acknowledgements}

This research was funded by English Heritage, through the Aggregates Levy Sustainability Fund (Project 3361), and their support is gratefully acknowledged. Our thanks to the two JQS referees for their time and many helpful comments, and also to Dr David Bridgland, Dr Andy Howard and Dr John McNabb for their many comments on early drafts and the ideas contained within this paper, with particular thanks to Dr Bridgland for his feedback regarding Figure 1. Naturally, all remaining omissions and errors are our own.

\section{References}

Anklin M, Barnola J-M, Beer J, Blunier T, Chappellaz J, Clausen HB, Dahl-Jensen D, Dansgaard W, Angelis M de, Delmas RJ, Duval P, Fratta M, Fuchs A, Fuhrer K, Gundestrup N, Hammer C, Iversen P, Johnsen S, Jouzel J, Kipfstuhl J, Legrand M, Lorius C, Maggi V, Miller H, Moore JC, Oeschger H, Orombelli G, Peel DA, Raisbeck G, Raynaud D, Schøtt-Hvidberg C, Schwander J, Shoji H, Souchez R, Stauffer B, Steffensen JP, Suevenard M, Sveinbjörnsdottir A, Thorsteinsson T, Wolff EW. 1993. Climate instability during the last interglacial period recorded in the GRIP ice core. Nature 364: 203-207.

Antoine P, Munaut A-V, Limondin-Lozouet N, Ponel P, Dupéron J, Dupéron M. 2003. Response of the Selle River to climatic modifications during the Lateglacial and Early Holocene (Somme Basin-Northern France). Quaternary Science Reviews 22: 2061-2076.

Ashton N, Lewis S. 2002. Deserted Britain: Declining Populations in the British Late Middle Pleistocene. Antiquity 76: $388-396$. 
Bibus E, Wesler J. 1995. The middle Neckar as an example of fluvio-morphological processes during the Middle and Late Quaternary period. Zeitschrift für Geomorphologie, Supplement Band 88: 15-26.

Bridgland DR. 1994. Quaternary of the Thames. Chapman and Hall: London.

Bridgland DR. 1995. The Quaternary sequence of the eastern Thames basin: problems of correlation. In The Quaternary of the Lower Reaches of the Thames: Field Guide, Bridgland DR, Allen P, Haggart BA (eds). Quaternary Research Association: Durham; 35-52.

Bridgland DR. 1996. Quaternary River Terrace Deposits as a Framework for the Lower Palaeolithic Record. In The English Palaeolithic Reviewed, Gamble CS, Lawson AJ (eds). Wessex Archaeology Ltd.: Salisbury; 23-39.

Bridgland DR. 2000. River terrace systems in north-west Europe: an archive of environmental change, uplift and early human occupation. Quaternary Science Review 19: 1293-1303.

Bridgland DR. 2001. The Pleistocene Evolution and Palaeolithic Occupation of the Solent River. In Palaeolithic Archaeology of the Solent River, Wenban-Smith FF, Hosfield RT (eds). Lithic Studies Society: London; 15-25.

Brown AG, Cooper L, Salisbury CR, Smith DN. 2001. Late Holocene channel changes of the Middle Trent: channel response to a thousand-year flood record. Geomorphology 39: 69-82.

Bryant ID. 1983. The utilization of arctic river analogue studies in the interpretation of periglacial river sediments from southern Britain. In Background to Paleohydrology, Gregory KJ (ed.). Wiley: Chichester; 413-431.

Büdel J. 1977. Klima-Geomorphologie. Gebrüder Borntraeger: Berlin.

Chambers JC. 2004. The spatial modelling of Palaeolithic secondary context assemblages: case studies from the Solent River System and Axe River Valley, UK. Unpublished PhD Thesis: University of Southampton.

Clayton KM. 1977. River Terraces. In British Quaternary Studies: Recent Advances, Shotton FW (ed.). Clarendon Press: Oxford; 153-168.

Cleveringa P, De Gans W, Huybrechts W, Verbruggen C. 1988. Outline of river adjustments in small river basins in Belgium and the Netherlands since the Upper Pleniglacial. In Lake, Mire and River Environments During the Last 15000 Years, Lang G, Schluchter C (eds). Balkema: Rotterdam; 123-132.

Collins PEF, Fenwick IM, Keith-Lucas MD, Worsley P. 1996. Late Devensian river and floodplain dynamics and related environmental change in northwest Europe, with particular reference to a site at Woolhampton, Berkshire, England. Journal of Quaternary Science 11(5): 357-375.

Conway B, McNabb J, Ashton N. 1996. Excavations at Barnfield Pit, Swanscombe 1968-1972. British Museum Occasional Paper No. 94. British Museum: London.

Gamble CS. 1999. The Palaeolithic Societies of Europe. Cambridge University Press: Cambridge.

Gibbard PL. 1985. The Pleistocene history of the Middle Thames valley. Cambridge University Press: Cambridge. 
Gibbard PL, Lewin J. 2002. Climate and related controls on interglacial fluvial sedimentation in lowland Britain. Sedimentary Geology 151: 187-210.

Green CP, McGregor DFM. 1980. Quaternary evolution of the River Thames. In The Shaping of Southern England, Jones DKC (ed.). Academic Press: London; 177-202.

Green CP, McGregor DFM. 1987. River Terraces: a stratigraphic record of environmental change. In International Geomorphology 1986 Part 1, Gardiner V (ed). Wiley: Chichester; 977-987.

Hosfield RT, Chambers JC. 2002. The Lower Palaeolithic site of Broom: geoarchaeological implications of optical dating. Lithics: The Newsletter of the Lithic Studies Society 23: 33-42.

Hosfield RT, Chambers JC. 2004. The Archaeological Potential of Secondary Contexts. English Heritage Project Report (Project No. 3361). English Heritage Archive Report: London.

Houben P, Nolte S, Rittweger H, Wunderlich J. 2001. Lateglacial and Holocene environmental change indicated by floodplain deposits of the Hessian Depression (Central Germany). In River Basin Sediment Systems: Archives of Environmental Change, Maddy D, Macklin MG, Woodward JC (eds). Balkema: Lisse; 249-264.

Houben P. 2003. Spatio-temporally variable response of fluvial systems to Late Pleistocene climate change: a case study from central Germany. Quaternary Science Reviews 22: 2125-2140.

Howard AJ, Macklin MG. 1999. A generic morphological approach to archaeological interpretation and prospection in British river valleys: a guide for archaeologists investigating Holocene landscapes. Antiquity 73: 527-541.

Huisink M. 1997. Late-glacial sedimentological and morphological changes in a lowland river in response to climatic change: the Maas, southern Netherlands. Journal of Quaternary Science 12(3): 209-223.

Johnsen SJ, Dahl-Jensen D, Gundestrup N, Steffensen JP, Clausen HB, Miller H, Masson-Delmotte V, Sveinbjörnsdottir AE, White J. 2001. Oxygen isotope and palaeotemperature records from six Greenland icecore stations, Camp Century, Dye-3, GRIP, GISP2, Renland and North Grip. Journal of Quaternary Science 16: 299-308.

Kasse C. 1998. Depositional Model for Cold-climate Tundra Rivers. In Palaeohydrology and Environmental Change, Benito G, Baker VR, Gregory KJ (eds). John Wiley \& Sons: Chichester; 83-97.

Lewis SG, Maddy D. 1999. Description and Analysis of Quaternary Fluvial Sediments: a case study from the Upper River Thames, UK. In The Description and Analysis of Quaternary Stratigraphic Field Sections, Jones AP, Tucker ME, Hart JK (eds). Quaternary Research Association: London; 111-135.

Lowe JJ, Walker MJC. 1997. Reconstructing Quaternary Environments (2 ${ }^{\text {nd }}$ Edition). Pearson Education Limited: Harlow.

Macklin MG, Lewin J. 1993. Holocene river alluviation in Britain. Zeitschrift für Geomorphologie, Supplement Band 88: $109-122$. 
Macklin MG, Lewin J, Woodward JC. 1995. Quaternary fluvial systems in the Mediterranean basin. In Mediterranean Quaternary River Environments, Lewin J, Macklin MG, Woodward JC (eds). Balkema: Rotterdam; 1-25.

Maddy D, Bridgland DR. 2000. Accelerated uplift resulting from Anglian glacioisostatic rebound in the Middle Thames valley, UK? Evidence from the river terrace record. Quaternary Science Review 19: 1581-1588.

Maddy D, Bridgland, DR, Westaway R. 2001. Uplift-driven valley incision and climate-controlled river terrace development in the Thames Valley, UK. Quaternary International 79: 23-36.

Maizels JK. 1983. Proglacial channel systems: change and thresholds for change over long, intermediate and short time-scales. In Modern and ancient fluvial systems, Collinson JD, Lewin J (eds). Blackwell Scientific Publications: Oxford; 251-266.

Mass GS, Macklin MG, Kirkby MJ. 1998. Late Pleistocene and Holocene river development in Mediterranean steepland environments, south-west Greece. In Palaeohydrology and Environmental Change, Benito G, Baker VR, Gregory KJ (eds). John Wiley \& Sons: Chichester; 153-165.

Meese DA, Gow AJ, Alley RB, Zielinsky GA, Grootes PM, Ram M, Taylor KC, Mayewski PA, Bolzan JF. 1997. The Greenland Ice Sheet Project 2 depth-age scale: methods and results. Journal of Geophysical Research 102: $411-423$.

Meinke K. 1995. The development of the middle and lower course of the Weser river during the Late Pleistocene. Zeitschrift für Geomorphologie, Supplement Band 88: 1-13.

Murray AS, Roberts RG. 1997. Determining the burial time of single grains of quartz using optically stimulated luminescence. Earth and Planetary Science Letters 152: 163-180.

Murray AS, Wintle AG. 2000. Luminescence dating of quartz using an improved single-aliquot regenerative-dose protocol. Radiation Measurements 32: 57-73.

Pastre J-F, Limondin-Lozouet N, Leroyer C, Ponel P, Fontugne M. 2003. River system evolution and environmental changes during the Lateglacial in the Paris Basin (France). Quaternary Science Reviews 22: 2177-2188.

Petit JR, Jouzel J, Raynaud D, Barkov NI, Barnola J-M, Basile I, Benders M, Chappellaz J, Davis M, Delaygue G, Delmotte M, Kotlyakov VM, Legrand M, Lipenkov VY, Lorius C, Pepin L, Ritz C, Saltzman E, Stievenard M. 1999. Climate and atmospheric history of the past 420,000 years from the Vostok ice core, Antarctica. Nature 399: $429-436$.

Prescott JR, Hutton JT. 1994. Cosmic ray contributions to dose rates for luminescence and ESR dating: large depths and long-term time variations. Radiation Measurements 23: 497-500. 
Roberts MB, Gamble CS, Bridgland DR. 1995. The earliest occupation of Europe: the British Isles. In The Earliest Occupation of Europe. Proceedings of the European Science Foundation Workshop at Tautavel (France) 1993, Roebroeks W, van Kolfschoten T (eds). Leiden University Press: Leiden; 165-191.

Roe DA. 1981. The Lower and Middle Palaeolithic Periods in Britain. Routledge and Kegan Paul Ltd: London.

Rose J. 1979. River terraces and sea level change. Brighton Polytechnic Geographic Society Magazine 3: 13-30.

Rose J, Turner C, Coope GR, Bryan MD. 1980. Channel changes in a lowland river catchment over the last 13,000 years. In Timescales in Geomorphology, Cullingford RA, Davidson DA, Lewin J (eds). John Wiley \& Sons Ltd: Chichester; 159-175.

Schirmer W. 1988. Holocene valley development on the Upper Rhine and Main. In Lake, Mire and River Environments During the Last 15000 Years, Lang G, Schluchter C (eds). Balkema: Rotterdam; 153-160.

Schirmer W. 1995. Valley bottoms in the late Quaternary. Zeitschrift für Geomorphologie, Supplement Band 100: $27-51$.

Shackleton NJ. 1987. Oxygen isotopes, ice volume and sea level. Quaternary Science Review 6: 183-190.

Sörgel W. 1921. Die Ursachen dur diluvialen Aufschotterung und Erosion. Berlin.

Stuiver M, Grootes P. 2000. GISP2 oxygen isotope ratios. Quaternary Research 53: 277-284.

Toms PS. 2002. The acquisition of equivalent dose estimates from natural sedimentary quartz using optically stimulated luminescence; Unpublished PhD thesis: University of London.

Toms P, Hosfield RT, Chambers JC, Green CP. 2004. Optical dating of the Broom Palaeolithic sites. English Heritage Archive Report: London.

Tuffreau A, Antoine P. 1995. The earliest occupation of Europe: continental northwestern Europe. In The Earliest Occupation of Europe. Proceedings of the European Science Foundation Workshop at Tautavel (France) 1993, Roebroeks W, van Kolfschoten T (eds). Leiden University Press: Leiden; 147-163.

Tuffreau A, Lamotte A, Marcy J-L. 1997. Land-Use and Site Function in Acheulean Complexes of the Somme Valley. World Archaeology 29(2): 225-241.

Vandenberghe J. 1993. Changing fluvial processes under changing periglacial conditions. Zeitschrift für Geomorphologie, Supplement Band 88: 17-28.

Vandenberghe J. 1995. Timescales, Climate and River Development. Quaternary Science Reviews 14: 631-638.

Vandenberghe J. 2002. The relation between climate and river processes, landforms and deposits during the Quaternary. Quaternary International 91: 17-23.

Vandenberghe J. 2003. Climate forcing of fluvial system development: an evolution of ideas. Quaternary Science Reviews 22: 2053-2060. 
Vandenberghe J, Kasse C, Bohncke S, Kozarski S. 1994. Climate-related river activity at the Weichselian-Holocene transition: a comparative study of the Warta and Maas rivers. Terra Nova 6: 476-485.

Van Balen RT, Houtgast RF, Van der Wateren FM, Vandenberghe J, Bogaart PW. 2000. Sediment budget and tectonic evolution of the Meuse catchment in the Ardennes and the Roer Valley Rift System. Global and Planetary Change 27: 113-129.

Van Huissteden J. 1990. Tundra rivers of the last glacial: sedimentation and geomorphological processes during the Middle Pleniglacial (Eastern Netherlands). Mededelingen Rijks Geologische Dienst 44(3): 1-138.

Van Huissteden J, Gibbard PL, Briant RM. 2001. Periglacial fluvial systems in northwest Europe during marine isotope stages 4 and 3. Quaternary International 79: 75-88.

Watts WA, Allen JRM, Huntley B. 1996. Vegetation history and palaeoclimate of the last glacial period at Lago Grande di Monticchio, southern Italy. Quaternary Science Reviews 15: 133-153.

White MJ. 1998. Twisted Ovate Bifaces in the British Lower Palaeolithic: Some Observations and Implications. In Stone Age Archaeology: Essays in Honour of John Wymer, Ashton N, Healy F, Pettitt P (eds). Oxbow Monograph 102 \& Lithic Studies Society Occasional Paper No. 6. Oxbow Books: London; 98-104.

Wymer JJ. 1968. Lower Palaeolithic Archaeology in Britain as Represented by the Thames Valley. John Baker: London.

Wymer JJ. 1999. The Lower Palaeolithic Occupation of Britain. Wessex Archaeology: Salisbury.

Zeuner FE. 1958. Dating the Past: An Introduction to Geochronology ( $4^{\text {th }}$ edition). Metherun and Co. Ltd.: London. 